\title{
A Corresponding Community: Dr Agnes Bennett and her Friends from the Edinburgh Medical College for Women of the 1890 s
}

\author{
BARBARA BROOKES*
}

On St Patrick's Day 1909, Dr Eleanor Sproull sat down in Bromley, England, to write her monthly letter to Dr Agnes Bennett, in Wellington, New Zealand. One of a group of women graduates in medicine who were close friends, Eleanor reflected on life since their student days in the late 1890s:

One begins the journey [of life] light of heart going along gaily with many companions ... these change ... and the number gets fewer, the road gets narrower, and at last one is all alone, it is dark and quiet - will any voice speak out of the silence? Will any hand stretch out of the solitude, will any light shine out of the darkness? ... Parts of me seem to atrophy as I go on-is that the beginning of death? ${ }^{1}$

Eleanor Sproull's depression, frequently admitted in her letters, was, she noted "a great deal due to the want of human fellowship". A School Medical Officer, living alone, she would often "spend days and speak to no one, except a few words to the children I examine". 2 Even the community of the church offered little comfort. Eleanor, who was deeply interested in spiritual matters, longed for women clergy as, she noted, "I have not yet found the man clerical who when he begins to talk to a woman on such subjects doesn't ... talk down to her". 3

Much has been written about the battle women had to enter the medical profession in the nineteenth century, but their personal and professional experience once qualified has received less attention. British, American and Canadian medical women have been the subject of important studies. ${ }^{4}$ Carol Dyhouse has charted the way in which London women medical students often described their pursuit of a medical education in terms of a mythical

(C) Barbara Brookes 2008

*Barbara Brookes, PhD, History Department, University of Otago, Box 56, Dunedin, New Zealand; e-mail: Barbara.brookes@stonebow.otago.ac.nz

The photographs reproduced with this article originally appeared in Cecil Manson and Celia Manson, Dr Agnes Bennett, London, Michael Joseph, 1960. We have tried unsuccessfully to trace the copyright holders of these photographs. If contacted, we will endeavour to rectify any errors or omissions.

\footnotetext{
${ }^{1}$ Bennett, Agnes Papers. MS-Papers-1346-218. Alexander Turnbull Library, National Library of New Zealand (hereafter: ATL, NLNZ). Letter from Eleanor Sproull, [17] March 1909.
}

\footnotetext{
${ }^{2}$ Bennett, Agnes Papers. MS-Papers-1346-218. ATL, NLNZ. Letter from Eleanor Sproull, 29 Sept. 1908.

${ }^{3}$ Bennett, Agnes Papers, MS-Papers-1346-219. ATL, NLNZ. Letter from Eleanor Sproull, 23 Dec. 1910.

${ }^{4}$ The standard histories relating to the British experience are Enid Moberley Bell, Storming the citadel: the rise of the woman doctor, London, Constable, 1953, and Catriona Blake, The charge of the parasols: women's entry to the medical profession, London, Women's Press, 1990. On the American experience, see Mary Roth Walsh, "Doctors wanted, no women need apply": sexual barriers in the medical profession, 1835-1975, New Haven, Yale University Press, 1977, and Regina Morantz-Sanchez, Sympathy and science: women physicians in American medicine, New York, Oxford University Press, 1985.
} 


\section{Barbara Brookes}

quest with a moment of revelation followed by obstacles to be overcome. ${ }^{5}$ The development of hospitals run by medical women, which gave them clinical experience and consultancy opportunities, has been explored by Mary Ann Elston, as have the careers of English women doctors from the 1860 s to the 1970 s. ${ }^{6}$ Irene Finn's examination of women in the medical profession in Ireland suggests that the women's "ability to meet male-defined standards of excellence" strengthened women's search for citizenship. ${ }^{7}$ Virginia Drachman, through the use of early surveys of American women doctors, has examined the "limits of progress" in the period 1881-1926, suggesting that women were confined to low-status female specialties, that combining a career and marriage continued to be difficult, and that women remained isolated within the profession. ${ }^{8}$ Studies of Australia and New Zealand have explored the first cohort of women doctors graduating from the University of Melbourne and the University of Otago respectively. ${ }^{9}$ Penny Russell's analysis of Melbourne's first thirty women medical graduates argues that they enjoyed their independence and responsibilities without altering "conventional notions" of womanhood. ${ }^{10}$ Louella McCarthy has explored why the strategy of separate medical institutions for women, which faded in the USA in the late nineteenth century, succeeded in Sydney in the interwar years. ${ }^{11}$

Most pertinent to this study is Wendy Alexander's examination of the origins and destinations of the early women graduates of Glasgow University. Alexander demonstrates that, while over 88 per cent of the graduates up to 1910 worked for at least some of their lives, they were over-represented in public health and Poor Law posts and underrepresented in general practice and hospital medicine, particularly in the voluntary hospitals. "Prejudice from male doctors and boards of management in appointments", she concludes, was "the main reason for this over concentration of women at the bottom of the profession", but it also resulted from their inability to obtain hospital residency posts which were "the key to most future opportunities". ${ }^{12}$

This article looks beyond the records of institutions, published memoirs of heroic journeys and the statistical detail of surveys to delve into the private feelings, preserved through their letters, of a small group of five friends who graduated from the Edinburgh Medical College for Women (EMCW) before $1900 .{ }^{13}$ The focus is on how individual

\footnotetext{
${ }^{5}$ Carol Dyhouse, 'Driving ambitions: women in pursuit of a medical education, 1890-1939', Women's History Review, 1998, 7 (3): 321-41, on pp. 323-25.

${ }^{6}$ Mary Ann Elston, “"Run by women (mainly) for women": medical women's hospitals in Britain, 1866-1948', in A Hardy and L Conrad (eds), Women and modern medicine, Amsterdam, Rodopi, 2001, pp. 73-108. Mary Ann Elston, 'Women doctors in the British health services: a sociological study of their careers and opportunities', PhD thesis, University of Leeds, 1986.

${ }^{7}$ Irene Finn, 'Women in the medical profession in Ireland, 1876-1919', in Bernadette Whelan (ed.), Women and paid work in Ireland 1500-1930, Dublin, Four Courts Press, 2000, pp. 102-19.

${ }^{8}$ Virginia G Drachman, 'The limits of progress: the professional lives of women doctors, 1881-1926', Bull. Hist. Med., 1986, 60: 58-72.
}

\footnotetext{
${ }^{9}$ Dorothy Page, 'Dissecting a community: women medical students at the University of Otago, 18911924', in B Brookes and D Page (eds), Communities of women: historical perspectives, Dunedin, University of Otago Press, 2002, pp. 111-27, p. 114.

${ }^{10}$ Penelope Russell, " "Mothers of the race": a study of the first thirty women medical graduates from the University of Melbourne', BA Hons thesis, Monash University, 1982.

${ }^{11}$ Louella McCarthy, 'Idealists or pragmatists? Progressives and separatists among Australian medical women, 1900-1940', Soc. Hist. Med., 2003, 16: $263-82$.

${ }^{12}$ Wendy Alexander, First ladies of medicine, Wellcome Unit for the History of Medicine, University of Glasgow, 1987, pp. 48, 57.

${ }^{13}$ I am grateful to Irene Ferguson, Special Collections, Edinburgh University Archives, for the
} 


\section{Dr Agnes Bennett and her Friends of the 1890s}

medical women coped with their lives when leaving behind the communal life of medical school. Letters, as Cécile Dauphin reminds us, are "never more than a dotted line" as a record of the past. They are, however, invaluable in gaining insights into personal and professional lives which are unrecorded elsewhere. ${ }^{14}$ Through their letters, I explore how the collective identity of this group of women, the sorority they forged in the Edinburgh Medical College for Women, helped to sustain their individual identities as they embarked on their separate careers in medicine. Through being written, the letters acted as performatives: they created a community very necessary to its members. They were, in themselves, a means of countering loneliness and isolation. ${ }^{15}$

At the centre of the group in one way, because of the survival of her papers which contain the letters, is the Australian, Agnes Bennett (1872-1960). Yet Bennett is also an absent centre since we do not have her communications to her correspondents, only the treasure trove of letters she received and carefully kept. We do, however, have letters she wrote to her family and her diaries. Her papers were gifted to the Alexander Turnbull Library, now part of the National Library of New Zealand. Bennett graduated MB ChB from the EMCW in 1899. A major medical figure in Wellington, New Zealand, she led a varied and very active life, recorded in a biography by Cecil and Celia Manson. ${ }^{16}$ It is the early years of her career that are the focus here when she and her friends were struggling to make professional careers.

\section{Five Friends}

Bennett's fellow Australian, Mary Booth (1869-1956), was the first of the friends to arrive at the EMCW in 1895. The eldest of three daughters of a Sydney schoolmaster, Mary Booth attended the University of Sydney where she overlapped with Agnes Bennett and graduated with a BA in 1890. After working as a governess for the children of the governor of New South Wales for two years, a legacy from her maternal grandfather gave her some financial independence, which she used to pursue medicine at the University of Melbourne in 1894. Clearly dissatisfied with her experience there, she decided to go to Scotland.

Biographical details of the three other friends are rather more sketchy since they did not become as prominent in later life as did Mary Booth and Agnes Bennett. The third Australian, Kate Welton Hogg, had a BA from Sydney University and entered the Sydney Medical School in 1895. The Dean, Professor Anderson Stuart, disapproved of women doing medicine, believing that their place was in the home. Failing to keep them out, he

following biographical information about the Edinburgh Medical College for Women graduates who are the focus of this paper: Agnes Lloyd Bennett, graduated MB, CM 1899 and MD 1911. Her thesis was entitled 'Some observations on early lactation in the women of New Zealand'. Kate Welton Hogg graduated MB ChB 1900 and MD 1909. Her thesis was entitled 'Some considerations on the etiology of dementia praecox'. Elizabeth Macrory graduated MB ChB 1900. Eleanor Rosina Sproull graduated MD ChB 1900 and MD 1908. Her thesis was entitled 'Infantile mortality. A short account of preventive measures in six Yorkshire towns: a general discussion of its causes and best means of prevention'.

${ }^{14}$ Cécile Dauphin, Opening and closing remarks at the Correspondence Colloquium, organized by Susan Foley, Kate Hunter and Charlotte Macdonald, Victoria University of Wellington, 23 and 24 June 2006. I am indebted to the organizers and all the participants at the colloquium for their most useful comments on this paper.

${ }^{15}$ Many thanks to Annabel Cooper for this useful insight into the correspondence.

${ }^{16}$ Cecil Manson and Celia Manson, Doctor Agnes Bennett, London, Michael Joseph, 1960. 


\section{Barbara Brookes}

believed "continual failures would finally discourage them": a policy that was apparently put into effect. ${ }^{17}$ After one year in the discouraging atmosphere of Sydney, Kate Hogg decided to go to Edinburgh where she graduated MB ChB in 1900 and MD in 1909. ${ }^{18}$

Two of the fellow EMCW graduates were Irish. Elizabeth Macrory was born in Belfast in 1869. She attended Queen's College, Belfast, for one year and entered the EMCW in 1895, aged twenty-six, graduating MB ChB in 1900. There are no letters from Elizabeth (nicknamed Patrick or Paddie) in the Bennett collection, but she is part of the circle of friends whose doings are regularly reported. Evidence in the letters makes it clear she was a woman of independent means, unlike her friend Eleanor Rosina Sproull, born in Carrickfergus in 1867. Eleanor appears to have done her preliminary examination at the Royal University of Ireland before beginning at the EMCW in 1895, aged twentyeight. She graduated MB ChB in 1900 and MD in 1908. Sproull is the "brightest star in the constellation" of letter writers who wrote regularly and introspectively to Bennett. ${ }^{19}$ It is often through her that we learn of the lives of the other friends. Her letters bear witness to the struggles of one medical woman as she left the supportive environment of the Edinburgh sorority of medical women and made her way as a doctor.

The letters from Agnes Bennett's friends, written at the time when they were trying to make their way rather than reflecting back on their careers, suggest that women doctors practising in the early twentieth century might be exiles from the communities in which they were raised and also from those in which they ended up living. In these letters we read less of the success of pioneering in a profession and more of the history of loneliness; an unexplored (and unexpected) cost of their professional lives.

The Edinburgh Medical College for Women was founded by Elsie Inglis and two other students in 1889-90. This occurred after Inglis and the Cadell sisters had revolted against Sophia Jex Blake's strict rules at the Edinburgh School of Medicine and went on to found their own school. In 1892, the College was placed on a firm foundation when it entered an agreement with the Edinburgh Royal Infirmary for the clinical training of its students. ${ }^{20}$ Agnes Bennett began at the EMCW in 1896. The friendships made at this time of hard work in medical training in Edinburgh were life-long and no doubt cemented by residence in the hostel that Elsie Inglis had founded for women students. Inglis proved an inspiration, both as a doctor and a leader of the Scottish women's suffrage movement. She was also hospitable and supportive of the women students, often having them to her home for Sunday afternoon tea. ${ }^{21}$

In the 1890 s, medicine was frequently held up as the pre-eminent field of achievement for women with academic talent, yet there were few other avenues of employment for women with an interest in science. However, the hopes of a glittering career and intellectual stimulation which may originally have inspired women to enter medicine quickly came up against the realities of making a living and the demands of families. The letters under examination here speak to the personal difficulties of the pursuit of success in

\footnotetext{
${ }^{17}$ M Hutton Neve, This mad folly! The history of Australia's pioneer women doctors, Sydney, Library of Australian History, 1980, p. 57.

${ }^{18}$ Ibid., p. 57.

${ }^{19}$ Thanks to Cécile Dauphin for this phrase.
}

\footnotetext{
${ }^{20}$ Shirley Roberts, Sophia Jex-Blake: a woman pioneer in nineteenth-century medical reform, London, Routledge, 1993, p. 179.

${ }^{21}$ Manson and Manson, op. cit., note 16 above, pp. 34-5.
} 


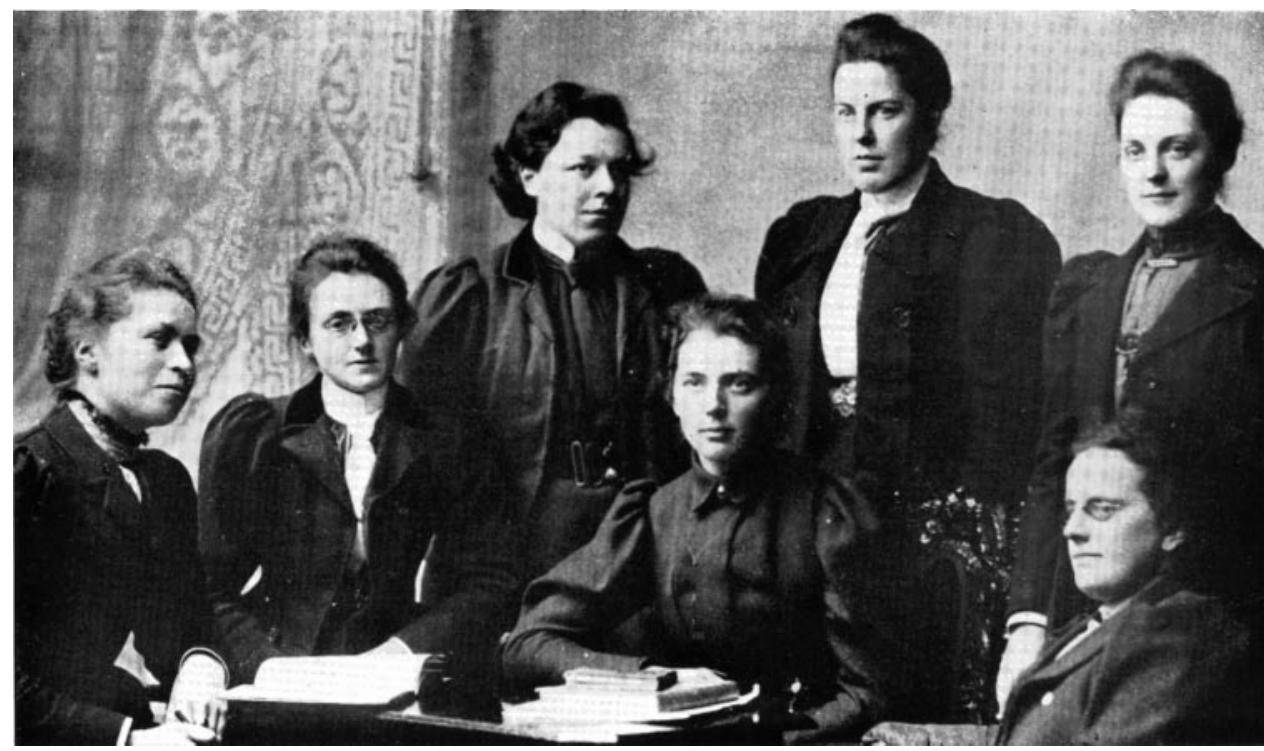

Figure 1: The women's medical school committee, Edinburgh, 1899. Agnes Bennett is the tallest, Eleanor Sproull is second from the left; the others are unidentified. (Photo from Cecil Manson and Celia Manson, Dr Agnes Bennett, London, Michael Joseph, 1960, opposite p. 64.)

medicine, and reinforce Drachman's argument about the "limits of progress" through highlighting individual subjectivity. The experience of this small sample complicates Anne Digby's assertion that women chose public appointments out of a moral imperative to serve. For some, the difficulties of succeeding in general practice and lack of alternatives forced the choice of state service. ${ }^{22}$

Agnes Bennett came from a family which valued education and knew about science. Her father was an "exceptionally able" engineer and Commissioner of Roads and Bridges for New South Wales. ${ }^{23}$ In pursuit of education, two girls and four boys of the family were taken to England by their mother. Agnes attended Cheltenham Ladies' College and Dulwich Girls' High School in London. The children returned to Sydney after their mother's death from smallpox, and Agnes attended Sydney Girls' High School. She won a state scholarship to study at Sydney University and graduated with a BSc in geology and biology in 1894, the first woman to gain a science degree with honours. She quickly found that even a distinguished record could not overcome the prejudice against employing a woman scientist and had to make do with teaching and governessing. ${ }^{24}$ She decided that medicine would allow her to follow her scientific interests (unlike the usual tale of women's devotion to alleviating the suffering of others), and since

\footnotetext{
${ }^{22}$ Anne Digby, The evolution of British general practice 1850-1948, Oxford University Press, 1999, p. 163.

${ }^{23}$ Beryl Hughes, 'Bennett, Agnes Elizabeth Lloyd 1872-1960', Dictionary of New Zealand biography,
}

Wellington, Auckland University Press/Department of Internal Affairs, vol. 3, p. 48.

${ }^{24}$ Beryl Hughes, 'Agnes Bennett', in Charlotte Macdonald, Merimeri Penfold and Bridget Williams (eds), The book of New Zealand women. Ko kui ma te 


\section{Barbara Brookes}

Edinburgh offered prestige as well as lower fees and living costs than Sydney, she decided to borrow money and go there with her friend Kate Hogg.

The first important friend Agnes had made while studying science at Sydney University in the early 1890s was Mary Booth. Determined to study medicine, Mary went from Sydney to Melbourne, studying biology with a professor whom, she noted, "strongly disapproves of girls going in for medicine". ${ }^{25}$ Undaunted, Mary went to Edinburgh and enrolled at the EMCW. She prepared the way for her two Sydney University friends Agnes and Kate.

I am [she wrote] longing to have you here, and if you don't come quickly you will find I have lost the power of speech for I see nobody except for a few minutes at lectures-there being no common room at the New School and the College being so far away we hardly see anything of one another. But when you come we shall have gay times "we three old bachelors from Sydney". ${ }^{26}$

Mary dreamt of the three women setting up a household together for "living alone isn't good for me or for one's work I fancy". 27

Agnes and Kate arrived in Edinburgh early in the morning of 24 February 1896, surprising Mary Booth, who was still in bed. Booth had arranged a comfortable and large room for them in her lodgings but they did, however, have to share a bed. ${ }^{28}$ The three women were forced to find other accommodation when the landlady's alcoholic nephew proved to be a trial. Eventually they moved into the hostel founded by Elsie Inglis. ${ }^{29}$ Soon the round of study began. After the first year Agnes wrote to her family, "Sometimes I feel I have undertaken \& risked too much oh I do pray I shall be able to be of some use to you all some day". ${ }^{30}$ The work was not always easy and there were a number of petty regulations to contend with which led Agnes to write to her family "if I don't learn anything else in Edinburgh I shall learn how to conduct a good solid rumpus-Sydney is not in it as far as that goes". ${ }^{31}$ In January 1898 Agnes reported dissecting the head and neck: on 20 January she recorded: "took out brain in morning". ${ }^{32}$ In February of that year she wrote to the family, "I still stand sighing on the threshold of medicine". 33

Agnes's friends provided invaluable support, and study was relieved by activities in their company-hockey on Saturdays for the women's medical team, ice skating, long walks (sometimes fourteen miles on a Sunday), the novelty of cycling, the routine of church, and tea parties. Elizabeth McElney and Elizabeth Macrory were amongst those friends and perhaps the latter was named "Patrick" or "Paddie" to distinguish between the two Irish women. ${ }^{34}$ The third of Agnes's Irish friends, Eleanor Sproull, became increasingly close to

$\overline{\text { kaupapa }}$, Wellington, Bridget Williams Books, 1991, p. 78.

${ }^{25}$ Bennett, Agnes. Papers. MS-Papers-1346-187. ATL, NLNZ. Letter from Mary Booth, 12 July 1893.

${ }^{26}$ Bennett, Agnes. Papers. MS-Papers-1346-187.

ATL, NLNZ. Letter from Mary Booth, 19 June 1895.

${ }^{27}$ Bennett, Agnes. Papers. MS-Papers-1346-187.

ATL, NLNZ. Letter from Mary Booth, 8 Sept. 1895.

${ }^{28}$ Bennett, Agnes. Papers. MS-Papers-1346-002. Diary 1895-96. ATL, NLNZ.

${ }^{29}$ Manson and Manson, op. cit., note 16 above, p. 31.

\footnotetext{
${ }^{30}$ Bennett, Agnes. Papers. MS-Papers-1346-84. ATL, NLNZ. Undated letter to family.

${ }^{31}$ Bennett, Agnes. Papers. MS-Papers-1346-84.

ATL, NLNZ. Letter to family, 10 Feb. 1898.

${ }^{32}$ Bennett, Agnes. Papers. MS-Papers-1346-003. ATL, NLNZ. Diary 1897.

${ }^{33}$ Bennett, Agnes. Papers. MS-Papers-1346-84. ATL, NLNZ. Letter to family, 10 Feb. 1898.

${ }^{34}$ Although never called anything other than Patrick or Paddie in the correspondence, this appears to be Miss E Macrory who was appointed as one of the two London County Council Inspectors of
} 


\section{Dr Agnes Bennett and her Friends of the 1890s}

her. Agnes recorded a long tramp they had taken in the Rutland Hills where they were caught in a snow storm, almost lost their way and were nearly blown off their feet- "yet we enjoyed it amazingly". ${ }^{35}$ Eleanor's family in Carrickfergus were very hospitable and Agnes went to stay with them a number of times. In September 1897 she recorded she was feeling "horribly blue about returning" to Edinburgh from Carrickfergus. ${ }^{36}$ In Edinburgh in 1899, when Agnes was struck by a severe bout of tonsillitis, Eleanor was "Dr, nurse and all". 37

Some of the harassments of their busy student days are recorded: a letter of apology from a member of the hospital staff to Miss Sproull, Miss Bennett and Miss McElney for turning off the "electric light when they were reading in Ward V Theatre of the Royal Infirmary"; a postcard from Kate Hogg describing how, when travelling by boat to France, a young man claiming to be a medical student pestered her at dinner and said women who studied medicine "were unsexed", at which she rose and left the table. ${ }^{38}$ Agnes Bennett recalled the "ancient, petty and contradictory by-laws" of the University which seemed "to be kept for the purpose of frustrating the students, especially the women". ${ }^{39}$ If the atmosphere in Edinburgh was chilly, it was no better elsewhere. Bennett recorded that, on a tour of Europe in the summer of 1898, she and her friend "took great care to conceal the fact that we were medical students. People seemed to be terrified of women medicos". ${ }^{40}$ By December that year she was thinking of going to India: "one seems to get such good work there". ${ }^{4}$

The friends' correspondence was renewed on leaving Edinburgh for different parts of the world. Kate Hogg went to Dublin and, in January 1901 was triumphant at having been appointed "Assistant Master" at the Coombe Hospital where many women postgraduate students (including Agnes Bennett) went to study maternal and infant welfare. Her letter was interrupted by a call to a case: "Oh! it's so lovely Agnes! not to have to call anyone else. I just sent for Paddie [her fellow EMCW graduate] to give an anaesthetic \& did internal version-child and mother alive and well after it. I was terribly pleased with myself." 42 Elation quickly turned to anger as the doctor in charge of the hospital "didn't back her claims" when she encountered difficulty with the nurses, a not uncommon occurrence when the newly trained women doctors were required to assert their authority over another group of women. ${ }^{43}$ "I'm glad I never became a nurse", wrote Eleanor Sproull, "they do get small and narrow." 44 Of the medical officer in charge, Kate reflected: "In me

Midwives, July 1908. London County Council, Public Health-County of London. Report of the Public Health Committee of the London County Council, submitting the Report of the Medical Officer of Health of the County, 1908.

${ }^{35}$ Bennett, Agnes. Papers. MS-Papers-1346-84. ATL, NLNZ. Letter to family, 10 Feb. 1898.

${ }^{36}$ Bennett, Agnes. Papers. MS-Papers-1346-003. ATL, NLNZ. Diary 1897.

${ }^{37}$ Bennett, Agnes. Papers. MS-Papers-1346-84 and 1346-003 (Diaries). ATL, NLNZ. Letter to family, 4 July 1899.

${ }^{38}$ Bennett, Agnes. Papers. MS-Papers-1346-198. ATL, NLNZ. Postcard from Kate Hogg, 23 July [1897?]

\footnotetext{
${ }^{39}$ Manson and Manson, op. cit., note 16 above, p. 32 .

${ }^{40}$ Ibid., p. 35.

${ }^{41}$ Bennett, Agnes. Papers. MS-Papers-1346-84. ATL, NLNZ. Letter to family, 29 Dec. 1898.

${ }^{42}$ Bennett, Agnes. Papers. MS-Papers-1346-198. ATL, NLNZ. Letter from Kate Hogg, 24 Jan. 1901.

${ }^{43}$ When the Sydney hospital was considering the appointment of a female resident in 1905, members of the Board stated that in their experience "nurses seemed to resent the authority of a lady doctor". Hutton Neve, op. cit., note 17 above, p. 78.

${ }^{44}$ Bennett, Agnes. Papers. MS-Papers-1346-218. ATL, NLNZ. Letter from Eleanor Sproull, 4 May 1908 .
} 


\section{Barbara Brookes}

I think he saw a draw for the women students. Once having got me he thought I was safe for a year ... [He said] if I did not choose to be agreeable it would be the worse for me."

Kate Hogg's difficulty with her superior increased when she challenged his practice of letting students continue to see maternity cases after they had dealt with a septic case, hence causing infection. She was clearly not "agreeable" and resigned in June 1901. ${ }^{45}$ Her experience was at odds with the 1900 Englishwoman's Year Book assessment that in Ireland "at college and hospital alike women are treated with the greatest courtesy and fairness". Fellow hospital staff, whether male doctors or female nurses, created one set of problems. The women's own families could create others. Elizabeth Macrory shared rooms with Kate Hogg in Dublin. Kate reported that Paddie's "family never will realise what a medical life means - they still expect her to fly to them \& it is a great strain on her \& takes her away a lot \& she missed a couple of good things from it too". ${ }^{4}$

\section{Family Expectations}

Evidence from outside this circle of friends indicates the responsibility that professional daughters felt towards their families. Daughters who had medical training and were themselves in good health appeared to many as the ideal carers for ailing parents or siblings. Professional training could not "save them, as marriage would have done, from the demands of their families". ${ }^{47}$ Indeed the fact that they were single made it their duty to care for family members. Two examples serve to illustrate this point. Mary Fletcher, an 1896 Melbourne graduate, began a practice in Sydney Road, Brunswick, but soon returned home to the family outback station "Kaleno" in New South Wales, because her mother was ill and required care. She also cared for an ill sister, educated another sister's children, and helped run the homestead. She retained her interest in medicine through reading journals and occasionally attended Aboriginal people in the district. ${ }^{48}$ Mary Baldwin, a 1902 Melbourne graduate, took up practice first in Perth and then in Calgoorlie, apparently accompanied by her sister. When both women were struck with diphtheria they returned to the family home in Kyneton. Mary nursed her sister to recovery through two years of illness but by then their father had been invalided through a carriage accident. Mary nursed him until his death, by which time her mother was ill. Her medical interests were maintained through some lecturing at Kyneton hospital. ${ }^{49}$

Kate Hogg, Agnes Bennett and Mary Booth escaped such family demands. Kate Hogg initially went to Dublin in part because Agnes Bennett and Mary Booth had returned to Sydney to set up as general practitioners and she could not see "what Sydney was going to do with a 3rd". ${ }^{50}$ Before her return to Sydney, however, Agnes found work in Scotland.

\footnotetext{
${ }^{45}$ Bennett, Agnes. Papers. MS-Papers-1346-198. ATL, NLNZ. Letter from Kate Hogg, 20 June 1901. Mary Ann Elston records a senior consultant's accusation of "neglecting patients and impertinence" against Eliza Dunbar Walker at the Bristol Royal Hospital for Sick Children in 1873, which she writes "was the first of many charges against medical women of breaches of professional decorum". Elston,

'Women doctors', op. cit., note 6 above, p. 213, n.51.
}

\footnotetext{
${ }^{46}$ Bennett, Agnes. Papers. MS-Papers-1346-198. ATL, NLNZ. Letter from Kate Hogg, 29 Jan. 1901.

${ }^{47}$ Russell, op. cit., note 10 above, p. 34.

${ }^{48}$ Ibid., p. 71.

${ }^{49}$ Ibid., pp. 34, 62, 71.

${ }^{50}$ Bennett, Agnes. Papers. MS-Papers-1346-198. ATL, NLNZ. Letter from Kate Hogg, 24 Jan. 1901. Ethel Williams set up in Newcastle in 1895 "on the grounds that cities with a population of over
} 


\section{Dr Agnes Bennett and her Friends of the 1890s}

She was initially selected as the Resident Medical Officer for the Edinburgh Royal Infirmary but the Board of Governors refused to ratify the appointment of a woman. The need for staff in the psychiatric service, however, overrode prejudice against women doctors and Agnes was accepted as Resident Medical Officer for the Larbert Mental Hospital in Stirlingshire where she served for fifteen months. ${ }^{51}$ Eleanor came to visit and stay regularly, while Kate and Paddie also visited. ${ }^{52}$

Opportunities for medical women in Edinburgh, indeed in Scotland, may well have been more circumscribed than in London where the students at the London School of Medicine for Women had access to the sponsorship and patronage of the women staff at the New Hospital for Women founded by Elizabeth Garrett Anderson. ${ }^{53}$ All of the Glasgow graduates prior to 1910 who won residencies in London, did so at one of four hospitals, two of which were run by women. ${ }^{54}$ The EMCW graduates were conscious of the advantages of the London-trained. Eleanor wrote to Agnes:

I always think the younger London woman is abominably arrogant, they think no one who isn't London is any good, but I have known several London duffers ... they are usually a lot better off \& that is a help in looking nicer but in lots of posts a Scotch grad is much preferred for practical work. ${ }^{55}$

The community formed at Edinburgh was, in part, defined against those trained elsewhere.

\section{Barriers to Success in Medicine}

Agnes returned to Sydney in 1901 and attempted to set up in general practice, recording proudly in an April diary entry "Plate put up at 94 Darlinghurst Rd". ${ }^{66}$ Lack of business, however, drove her to fall back on psychiatric work once again, at the Callan Park Asylum. ${ }^{57}$ In this she was not alone. Irene Finn has noted that psychiatric work became a mainstay for three Irish women medical graduates of the 1890s during a brief period of "remarkable expansion and reform of the asylum system". 58 The same was true of Glasgow graduates: the most common residency obtained before 1900 was in an asylum. ${ }^{59}$ The unpopularity and low status of asylum work made it less of a positive choice for medical women than a field where they could always find work. ${ }^{60}$

250,000 could support a woman general practitioner", Elston, 'Women doctors', op. cit., note 6 above, p. 243.

${ }^{51}$ Hutton Neve, op. cit., note 17 above, p. 116.

Hughes, 'Agnes Bennett', op. cit., note 24 above, pp. $78-81$.

${ }^{52}$ Bennett, Agnes. Papers. MS-Papers-1346-004. Diary 1900. ATL, NLNZ.

${ }^{53}$ My thanks to Mary Ann Elston for this observation.

${ }^{54}$ Alexander, op. cit., note 12 above, p. 43.

${ }^{55}$ Bennett, Agnes. Papers. MS-Papers-1346-219.

ATL, NLNZ. Letter from Eleanor Sproull, [1911?].

${ }^{56}$ Bennett, Agnes. Papers. MS-Papers-1346-005. Diary 1900. ATL, NLNZ.

${ }^{57}$ Rosamond Benham who graduated from Adelaide in 1902, tried to set up a general practice in Melbourne in 1918. When she was unsuccessful, she worked at Sunbury Asylum and later Kew Asylum. See South Australian Medical Women's Society, The hands of a woman: stories of South Australian medical women and their society, Kent Town, South Australia, Wakefield Press, 1994,

p. 26. Elston's British study estimated that it took women three to four years in general practice before recovering costs; 'Women doctors', op. cit., note 6 above, p. 241.

${ }^{58}$ Finn, op. cit., note 7 above, p. 111.

${ }^{59}$ Alexander, op. cit., note 12 above, p. 43.

${ }^{60}$ Diana Gittins, Madness in its place: narratives of Severalls Hospital, 1913-1997, London, Routledge, 1998, p. 122. 


\section{Barbara Brookes}

By 1904 Kate Hogg was back in Sydney treading "the uphill road of making one's way in private practice". Her patient numbers were gradually increasing but "there are still some who come 'because they wouldn't for the world go to a doctor about such a thing'". She wrote to Bennett: "I am still living alone altho' I am always hoping some congenial soul will someday come along with whom I may feel I could chum up with. But one chums up much less easily as the years go on I fear." 61 Sydney proved to be a particularly uncongenial environment for women doctors wishing to get ahead. None of the boards of the metropolitan general public hospitals would accept women for postgraduate training and so they were forced to go to states other than New South Wales for their hospital experience. When Dr Susie O'Reilly, an outstanding scholar, was refused a residency at the Sydney hospital in 1905, both Mary Booth and Kate Hogg protested. In a letter to the Daily Telegraph, Mary Booth pointed to the very successful appointment of a woman doctor to the Out Patients' Department of the Women's Hospital, and the "signal success" of the Gynaecological Department of the Medical Mission Dispensary, Sydney, where only women worked. These examples showed that women wished to be attended by women, and, she noted, "that curiously enough, women have feelings too". In the same paper Kate Hogg wrote as "one who has been watching with keen interest the fag end of a struggle against old time prejudices":

Knowing as I do the atmosphere in which women work in Edinburgh, Dublin and Paris, I have seen in contrast the disabilities with which women students in N.S.W. are contending. I have had the opportunity of seeing something of the excellent work done by women here-work which compares most favourably with that done in the Old World. Where is the stimulus that comes from the knowledge that those who are training them believe in the need for their work, and in the certainty of a sphere of usefulness to follow? ${ }^{62}$

Despite these protests, the medical fraternity of Sydney continued to remain hostile to postgraduate opportunities for women, only one being appointed (and she was dismissed and reinstated after a furore) before $1910 .{ }^{63}$

Another EMCW graduate, Dr Isabel Watson, found it easier to set up practice in Wellington, New Zealand, though the early days were financially precarious and she suffered from such a lack of confidence that she experienced "tremors when the doorbell [rang]". ${ }^{64}$ By April 1905, however, Isabel felt she was "really becoming firmly established": and some successful cases had given her "some of that valuable confidence in oneself which I so sadly lacked". She had lately felt "a kind of general respect shown to me" and believed that she had "proved to many the possibility of being a Doctor and a woman". ${ }^{65}$ By June that year, Isabel was engaged and asked Agnes Bennett if she would consider moving to Wellington and taking up the practice, an offer that was promptly accepted. ${ }^{66}$ At a time when marriage generally meant abandoning a career,

\footnotetext{
${ }^{61}$ Bennett, Agnes. Papers. MS-Papers-1346-198. ATL, NLNZ. Letter from Kate Hogg, 24 Jan. 1901.

${ }^{62}$ Daily Telegraph, 7 Jan. 1905, reprinted in

Hutton Neve, op. cit., note 17 above, pp. 80-1.

${ }^{63}$ The story is recounted in ibid., pp. 84-102.

${ }^{64}$ Bennett, Agnes. Papers. MS-Papers-1346-223.

ATL, NLNZ. Letters from Isabel Watson, 5 Oct. 1904; 20 April 1905.
}

\footnotetext{
${ }^{65}$ Bennett, Agnes. Papers. MS-Papers-1346-223. ATL, NLNZ. Letter from Isabel Watson, 20 April 1905.

${ }^{66}$ Bennett, Agnes. Papers. MS-Papers-1346-223. ATL, NLNZ. Letters from Isabel Watson, 5 Oct. 1904; 20 April 1905.
} 


\section{Dr Agnes Bennett and her Friends of the 1890s}

the abandonment of one woman's career through marriage could create a welcome opportunity for another.

Agnes Bennett soon became a well-known and successful practitioner in Wellington. She was the only one amongst the close friends with whom she trained who succeeded in general practice, supplemented by work for the state. In 1908 she was appointed medical superintendent of the Wellington St Helens Hospital, which provided state-subsidized maternity care for the wives of working men who earned less than four pounds per week. A New Zealand innovation, the St Helens hospitals-seven of which were established between 1905 and 1920 - were also to be key sites of training for state-registered midwives. ${ }^{67}$ In effect, the state created women-only hospitals although not all the medical superintendents were women. Agnes Bennett in Wellington and Emily Seideberg in Dunedin gave long and dedicated service to their respective institutions. The maternal mortality rates at the St Helens hospitals were low and the hospitals helped establish high standards of midwifery. ${ }^{68}$ Bennett prided herself on the results achieved, commenting after a visit to Queen Charlotte's hospital in London that "it is a very miserable show-St H's can run rings around their methods". ${ }^{69}$ When looking forward to a visit from Agnes in 1910, Eleanor Sproull wrote:

It is so nice that you are doing so well. My! Won't we be proud of you when we get you over here, no turning your nose up my dear at dirty little School Inspectors who have no motor cars, \& no house, \& no nothing, just one of the Rubbish Heap. ${ }^{70}$

Wellington was clearly more congenial than Sydney in its attitude towards women doctors, but there were still battles to be fought. In a public address to the Second Annual Conference of the Society for Promoting the Health of Women and Children in 1909, Dr Ferdinand Batchelor, obstetrician and prominent medical school lecturer, claimed that the education of girls was detrimental to the race:

Our present educational system encourages and invites young women to enter a course of study for which Nature never intended them ... The average male (medical) student and sometimes the student below the average, usually turns out a fairly useful and successful practitioner: the brilliant female student at the best only attains mediocrity. ${ }^{71}$

Batchelor's remarks were enthusiastically supported by Dr Frederic Truby King, the asylum superintendent who had founded the Society and had earlier campaigned against the "evils of cram". ${ }^{72}$ Otago-trained Dr Emily Siedeberg reacted sharply against the pillars of her Dunedin medical community, pointing out that, in her own case and that of the other women who had passed through Otago, "the study was never felt to be a mental tax. It came as easy to us as simple housework comes to the ordinary girl". It was the girls "kept at

${ }^{67}$ Charlotte M Parkes, 'The medicalisation of New Zealand's maternity services, 1904-1937', in Linda Bryder (ed.), A healthy country: essays on the social history of medicine in New Zealand, Wellington, Bridget Williams Books, 1991, pp. 165-80, p. 166.

${ }^{68}$ Philippa Mein Smith, Maternity in dispute: New Zealand 1920-1939, Historical Publications Branch, Department of Internal Affairs, 1986, p. 117.

${ }^{69}$ Bennett, Agnes. Papers. MS-Papers-1346-177. ATL, NLNZ. Letter from Bennett to Ada Patterson, 14 July 1925.
${ }^{70}$ Bennett, Agnes. Papers. MS-Papers-1346-219. ATL, NLNZ. Letter from Eleanor Sproull, July 1910.

${ }^{71}$ Cited in Manson and Manson, op. cit., note 16 above, p. 63.

${ }^{72}$ Barbara Brookes, 'Frederic Truby King', Dictionary of New Zealand biography, Wellington, Bridget Williams Book/Department of Internal Affairs, 1993, vol. 2, pp. 257-8. Mary King, Truby King, the man, London, Allen and Unwin, 1948. 


\section{Barbara Brookes}

home with no mental interests who develop neurasthenia in the most marked degree". Agnes Bennett also responded in the pages of the Dominion, the Wellington newspaper:

That women in the medical profession only reach mediocrity is a statement as unfair as it is untrue. One day spent at the New Hospital in London (entirely officered and managed by women) would completely disillusion Dr Batchelor if he would go to it with an open mind ... The true crux of the whole question is the trained mind. The best training for any walk of life is that which teaches a boy or girl sound reason and good judgement and "empire over self" ... Some channels there must be for women's faculties. It is perfectly hopeless to expect her not to change with the times.

To cut girls off from intellectual pursuits, she wrote, "is only on a par with the cruelty of lifting a curtain and displaying a forbidden feast to a starving man". 73

By 1910, however, there were at least five "lady doctors" practising in Wellington. One of them, Elizabeth Gunn, was complaining of "slackness of trade" by 1911, which may have been the reason she chose to join the New Zealand School Medical Service when it was founded in 1912. ${ }^{74}$ Eleanor McLaglan, an Otago graduate, suggested that it was the hostility of male doctors that drove her into what she regarded as the pedestrian work of the School Medical Service. ${ }^{75}$ By 1914 , the School Medical Service was staffed by four women doctors, whom the Minister of Education referred to as "my four clever girls". ${ }^{76}$ Despite these developments, the issue of women's education had not yet been laid to rest. By the time of the 1913 conference of the Australasian Medical Association, Truby King had carved out an important national reputation in child welfare. ${ }^{77}$ King placed a motion on the agenda suggesting that the academic education of women was bad for the nation. Agnes Bennett was asked to respond by her medical associates and she did so with a passion that swayed the audience against the motion. ${ }^{78}$

Women in New Zealand had been enfranchised in 1893 but the continuing debate over women's suffrage in England gave Eleanor Sproull an opportunity to reflect on the wider question of married women working which, she considered, men regarded "in a most off hand manner". "They think the homes \& themselves would be better looked after if they didn't—and the question is rarely justly considered."79 The women's movement offered Eleanor fellowship in a cause. A 1908 poll of medical women indicated that the vast majority (538) supported women's suffrage with only fifteen opposed..$^{80}$ Eleanor's support was not, she wrote, simply because of:

... the mere and trivial question of the vote, it is the whole principle of women's status and it has been so educative to hundreds of well-to-do girls and women whose lives were full of nothingsfashion—dress etc to have learned to have suffered for a cause, to be laughed at ... ${ }^{81}$

${ }^{73}$ Cited in Manson and Manson, op. cit., note 16 above, pp. 62-5.

${ }^{74}$ Margaret Tennant, 'Elizabeth Gunn, 1879-1963', in Macdonald, et al. (eds), note 24 above, p. 267.

${ }^{75}$ Margaret Tennant, "“Missionaries of health": the School Medical Service during the inter-war period', in Bryder (ed.), op. cit., note 67 above, pp. $128-48$, p. 130.

${ }^{76}$ Derek Dow, Safeguarding the public health: a history of the New Zealand Department of Health, Wellington, Victoria University Press, 1995, p. 79.

\footnotetext{
${ }^{77}$ See Philippa Mein Smith, Mothers and king baby, Basingstoke, Macmillan, 1997, pp. 111-13.

${ }^{78}$ Manson and Manson, op. cit., note 16 above, pp. 68-9.

${ }^{79}$ Bennett, Agnes. Papers. MS-Papers-1346-218. ATL, NLNZ. Letter from Eleanor Sproull, 31 July [1909?].

${ }^{80}$ Elston, 'Women doctors', op. cit., note 6 above, p. 185.

${ }^{81}$ Bennett, Agnes. Papers. MS-Papers-1346-218. ATL, NLNZ. Letter from Eleanor Sproull, 8 July 1907.
} 


\section{Dr Agnes Bennett and her Friends of the 1890s}

Between 1909 and 1911, Eleanor took part in suffrage processions in London, writing excitedly to Agnes of a June 1911 demonstration, "I wouldn't miss it for anything, the Irish walk first in front of the New Zealanders". ${ }^{82}$ She pondered joining the militants, although she did not agree with all their acts, she admired their "brave struggle \& suffering". 83 She was particularly irked that Irish agitators were treated as political prisoners while suffragists were sent to Holloway prison and treated as "ordinary prisoners". After attending a dinner to greet twenty-four women released from prison, including Lady Constance Lytton, Eleanor described them as a "fine set of women", adding, "They are never a bit anti-man, tho' very much anti-government". ${ }^{84}$ The thought of men legislating on matters which "intimately affect women" raised Eleanor's ire. One of those "intimate matters" was the control of venereal disease, which through the debates over the Contagious Diseases Acts, was a matter of concern to English feminists. Eleanor discussed a case she had seen in Belfast where a husband went to Dublin with his football team and, through drinking, "lost self control". He reported his doctor's judgement to his wife that he was "not infectious" but despite that verdict gave her the infection. The wife came to Dr Sproull for treatment. ${ }^{85}$

The intimate matter of marriage at times preoccupied Eleanor and Agnes in their correspondence. Marriage was on Agnes's mind in 1908 but in the event never happened. Eleanor shared her disappointment: "As you say children \& husband often give as much sorrow as joy-but if it is greater pain it is also greater joy and one at least feels one has lived life." ${ }^{86}$ Eleanor wrote that she wished she had married; she had had a romance with a man in Belfast, "but he had been engaged for years to another woman \& I believe she wdn't release him, so they married!"

You know I think it's horrid to finish one's life undeveloped. I am not sure but I think if I had to live it over again I should like to have married, one has an interest then in the future \& that means so much as one grows older, but now I don't think I could marry I have got too accustomed to paddling my own canoe. ${ }^{87}$

She envied her friend Margaret, a doctor in Manchester, who was to be married: "I suppose she'll have a nice lot of healthy kids \& I shall be so envious of that if I had my life over again I would do my best to have at least one somehow - at least I think I would." 88 When Margaret gave birth to a daughter, Eleanor was critical of the fact that she was attended by a male doctor- "it strikes me as a sort of betrayal of the women's cause". Indeed this

\footnotetext{
${ }^{82}$ Bennett, Agnes. Papers. MS-Papers-1346-218. ATL, NLNZ. Letter from Eleanor Sproull, 13 June 1911.

${ }^{83}$ Bennett, Agnes. Papers. MS-Papers-1346-219. ATL, NLNZ. Letter from Eleanor Sproull, 1909[?].

${ }^{84}$ Bennett, Agnes. Papers. MS-Papers-1346-218. ATL, NLNZ. Letter from Eleanor Sproull, 5 April 1909.

${ }^{85}$ Bennett, Agnes. Papers. MS-Papers-1346-219. ATL, NLNZ. Letter from Eleanor Sproull, c.1914[?].
}

\footnotetext{
${ }^{86}$ Bennett, Agnes. Papers. MS-Papers-1346-218. ATL, NLNZ. Letter from Eleanor Sproull, 14 June 1909.

${ }^{87}$ Bennett, Agnes. Papers. MS-Papers-1346-218. ATL, NLNZ. Letter from Eleanor Sproull, 31 July 1909.

${ }^{88}$ Bennett, Agnes. Papers. MS-Papers-1346-219. ATL, NLNZ. Letter from Eleanor Sproull, 7 Sept. 1910.
} 


\section{Barbara Brookes}

perceived act of betrayal made her feel differently towards her friend. ${ }^{89}$ When she learned of Kate Hogg's marriage plans, Eleanor wrote to Agnes,

I expect this has been a hard time for you as not only the thought of losing $\mathrm{K}$. but few of us are so unselfish that we can rejoice without pain in seeing another gain happiness such as we fain would have for ourselves. ${ }^{90}$

Agnes wrote asking if she ever thought of the two of them "joining forces and coming together again", Eleanor replied:

... it is always at the back of my mind \& [God?] only knows what the future holds - we are bothat any rate I know I am-lonely women-I have lots of friends-but you stand quite apart, you [take?] a bit of my life which no other woman does or ever will- that is all I can say as things are now, so long as Mother lives I stay here. ${ }^{91}$

The marriage of Eleanor's sister in 1909 created the dilemma of who should care for their eighty-year-old mother. Eleanor believed it was her duty to take up this task, yet she had no savings. The "sure pay" of her public health job was "paltry" 92 but the work was interesting and she intended completing a thesis on infant mortality in York. "It would simplify things if Mother would come and live with me", Eleanor wrote, "but I cannot feel it fair to ask her to pull up roots of nearly 50 years". She knew that if she gave up work at that point it meant "for always as at my age re-entry would be hopeless". Fortunately, in the end, her family refused to let her sacrifice her career. ${ }^{93}$

Some women doctors solved the problem of living alone by following the example of Dr Elsie Inglis and setting up practice with fellow women practitioners. Jessie Macgregor had been a student with Elsie Inglis at the Jex Blake Edinburgh School in the late 1880s and they opened a practice together in Edinburgh. ${ }^{94}$ Others, such as Dr Mary Gordon, had intense emotional relationships with women. ${ }^{95}$ Mary Gordon's vision of contentment entailed sharing her life with another woman: a vision she described her 1936 book entitled Chase of the wild goose: the story of Lady Eleanor Butler and Miss Sarah Ponsonby. ${ }^{96}$ By the 1930s, Anne Digby suggests, "medical women in partnership were a well-established phenomenon". Mary Ann Elston's analysis further suggests that marriage was more likely among the first generation of women graduates than among the second, who found it more difficult to combine with a career. ${ }^{97}$

${ }^{89}$ Bennett, Agnes. Papers. MS-Papers-1346-219. ATL, NLNZ. Letter from Eleanor Sproull, 1911.

${ }^{90}$ Bennett, Agnes. Papers. MS-Papers-1346-219. ATL, NLNZ. Letter from Eleanor Sproull, 17 Aug. [1914?].

${ }^{91}$ Bennett, Agnes. Papers. MS-Papers-1346-218. ATL, NLNZ. Letter from Eleanor Sproull, 24 May [1907?].

${ }^{92}$ Bennett, Agnes. Papers. MS-Papers-1346-218. ATL, NLNZ. Letter from Eleanor Sproull, 10 April [1907?]

${ }^{93}$ Bennett, Agnes. Papers. MS-Papers-1346-218. ATL, NLNZ. Letter from Eleanor Sproull, 8 July 1909.

\footnotetext{
${ }^{94}$ Leah Leneman, In the service of life: the story of Elsie Inglis and the Scottish Women's Hospitals, Edinburgh, Mercat Press, 1994, p. 1.

95 Bennett, Agnes. Papers. MS-Papers-1346-197. ATL, NLNZ. Letter from Mary Gordon, 8 Dec. 1925.

${ }^{96}$ Mary Louisa Gordon, Chase of the wild goose: the story of Lady Eleanor Butler and Miss Sarah Ponsonby, London, Hogarth Press, 1936; reissued as The Llangollen ladies: the story of Lady Eleanor Butler and Miss Sarah Ponsonby, London, John Jones, 1999.

${ }^{97}$ Elston, 'Women doctors', op. cit., note 6 above, p. 170.
} 


\section{Dr Agnes Bennett and her Friends of the 1890s}

Of Agnes Bennett's correspondents, Elizabeth Macrory eventually took a job in Poplar, East London, in a dispensary run by Dr Ethel Lamport. She considered whether she should buy the practice. Patient numbers, however, did not increase and Eleanor reported: "I am very sorry for her as I fear she is beginning to look upon herself as partly cause of the failure, \& probably she is, just by reason of her best qualities, she hasn't an atom of commercialism in her." 98 On the other hand, Eleanor clearly admired Patrick's gregariousness (perhaps made possible by her independent means): "She is most hospitable and her flat is like a small hotel" with various people staying, including a cousin training in social work. Eleanor wrote, "It is very nice for P. having her, as I'm sure what I loathe is living alone, that is the hardest part of the working woman's life." 99

\section{Working for the State}

The expanding state health sector in England, Australia and New Zealand offered women doctors some financial and professional security, albeit at lower wages and with fewer prospects for advancement than were open to men in the sector. ${ }^{100}$ In 1909 Elizabeth Macrory was appointed Inspector of Midwives under the London Country Council, a post she still occupied in 1912. Eleanor reported her satisfaction that Patrick was settled and no longer faced the uncertainty of general practice. Eleanor loved her work in public health in Huddersfield where she visited all newly confined working-class mothers, supervised midwives and inspected women's working conditions. ${ }^{101}$ The pay was so poor, however, that she was forced to look for better paid work. She was not confident of her chances of finding something: "My age goes against me I'm sure, - if I were only pretty there is no doubt that's what tells with your committee men." 102

The School Medical Service in England and Wales was set up by the Education (Administrative Provisions) Act and came into force in 1908. It became incumbent upon local education authorities to provide medical inspection of children at the time of their admission to elementary school. ${ }^{103}$ In discussing this new requirement, Rochdale Council considered that "the appointment of a lady would be economical as well as useful": a consideration that no doubt influenced other councils. ${ }^{104}$ By 1909 there were five fulltime women medical officers of health acting as school medical officers in local authority areas compared with 284 men. ${ }^{105}$ Eleanor Sproull noted that there were "a good many posts for women cropping up just now", and she applied for a number. Eventually she was

${ }^{98}$ Bennett, Agnes. Papers. MS-Papers-1346-218. ATL, NLNZ. Letter from Eleanor Sproull, 9 Feb. [1908?].

${ }^{99}$ Bennett, Agnes. Papers. MS-Papers-1346-218. ATL, NLNZ. Letter from Eleanor Sproull, 26 June 1910.

${ }^{100}$ Elston's study indicates this was certainly the case in England. More work needs to be done to see if this was the case in New Zealand and Australia.

Elston, 'Women doctors', op. cit., note 6 above, p. 258.

${ }^{101}$ Bennett, Agnes. Papers. MS-Papers-1346-218. ATL, NLNZ. Letter from Eleanor Sproull, 10 April [1907?].
${ }^{102}$ Bennett, Agnes. Papers. MS-Papers-1346-218. ATL, NLNZ. Letter from Eleanor Sproull, 19 March [1908?].

${ }^{103}$ Bernard Harris, The health of the schoolchild: a history of the School Medical Service in England and Wales, Buckingham, Open University Press, 1995, p. 2.

${ }^{104}$ Steven Taylor, 'The development of the School Medical Service and the decline of the half-time system, 1880-1920', PhD thesis, Education, University of Manchester, 1996, p. 228.

${ }^{105}$ Harris, op. cit., note 103 above, p. 56. 


\section{Barbara Brookes}

appointed to a position in Bromley, Kent, where the salary began at $£ 200$ and rose to $£ 300$. After a few months she wrote:

I think they started this Med. Exam of Schl children too quickly \& didn't let it evolve-in the bigger over-crowded towns it may be necessary, but in country places like this I don't know yet that the game is worth the candle. If I were the Council, what I would do would be to appoint a whole time M.O.H. to do the Schl work \& then give him a nurse - the M.O.H. here is part time \& a busy practitioner but the last thing this Council will do will be to ask advice! ${ }^{106}$

The work was far less rewarding, though better paid, than her public health work. Eleanor doubted whether she or Patrick would ever have succeeded in general practice noting that "two failures takes away so much of one's self-confidence". ${ }^{107}$ She gave thanks that the government "stepped in and saved us from starvation". 108

Eleanor and Patrick were Irish but both worked in England. The Australian, Mary Booth, the pioneer among Agnes Bennett's friends, built a career in Sydney, based on contracts from groups such as the Australian Mutual Provident Society. Like many other women, she relied on government posts being, successively, an anthropometrist in the Department of the Government Statistician, a lecturer in Hygiene for the Department of Public Instruction, and appointed by the Victorian Department of Education to help establish the first school medical service in that state. She was deeply involved in women's organizations, including founding membership of the Women's Club in 1901 and the vice-presidency of the National Council of Women of New South Wales. Her long and very active career traversed a number of patriotic causes and evinced her concern for the well-being of women and children. ${ }^{109}$

Kate Hogg's initial success in general practice in Sydney did not, it seems, continue, and she eventually moved to Wellington, apparently as a locum for Agnes Bennett. She considered whether to stay in Wellington: it was "a dull place but a good place to work" and she thought it might provide the opportunity to establish herself as a skin specialist. A part-time government appointment would make it easier for her to build a practice. ${ }^{110}$ By 1914 she was sharing Agnes's house, an arrangement which made Eleanor Sproull green with envy: a "congenial companion forsooth madame the Gods favour you". ${ }^{111}$ The ideal arrangement did not, however, last and Eleanor was soon commiserating with Agnes about Kate's decision to marry. That decision, not unusually, entailed abandoning her career.

Like Mary Booth in Sydney, Agnes Bennett played a vital role in a number of organizations in Wellington devoted to furthering the interests of women: the Wellington Branch of the Federation of University Women, and the Women's War Service Auxilliary to name two. Hers was an extremely busy and full life: she worked in Serbia for the Scottish

\footnotetext{
${ }^{106}$ Bennett, Agnes Papers. MS-Papers-1346-218. ATL, NLNZ. Letter from Eleanor Sproull, 7 July 1908.

${ }^{107}$ Bennett, Agnes. Papers. MS-Papers-1346-218. ATL, NLNZ. Letter from Eleanor Sproull, 18 Aug. [1909?].

${ }^{108}$ Bennett, Agnes. Papers. MS-Papers-1346-219. ATL, NLNZ. Letter from Eleanor Sproull, 7 Sept. 1910.
} 


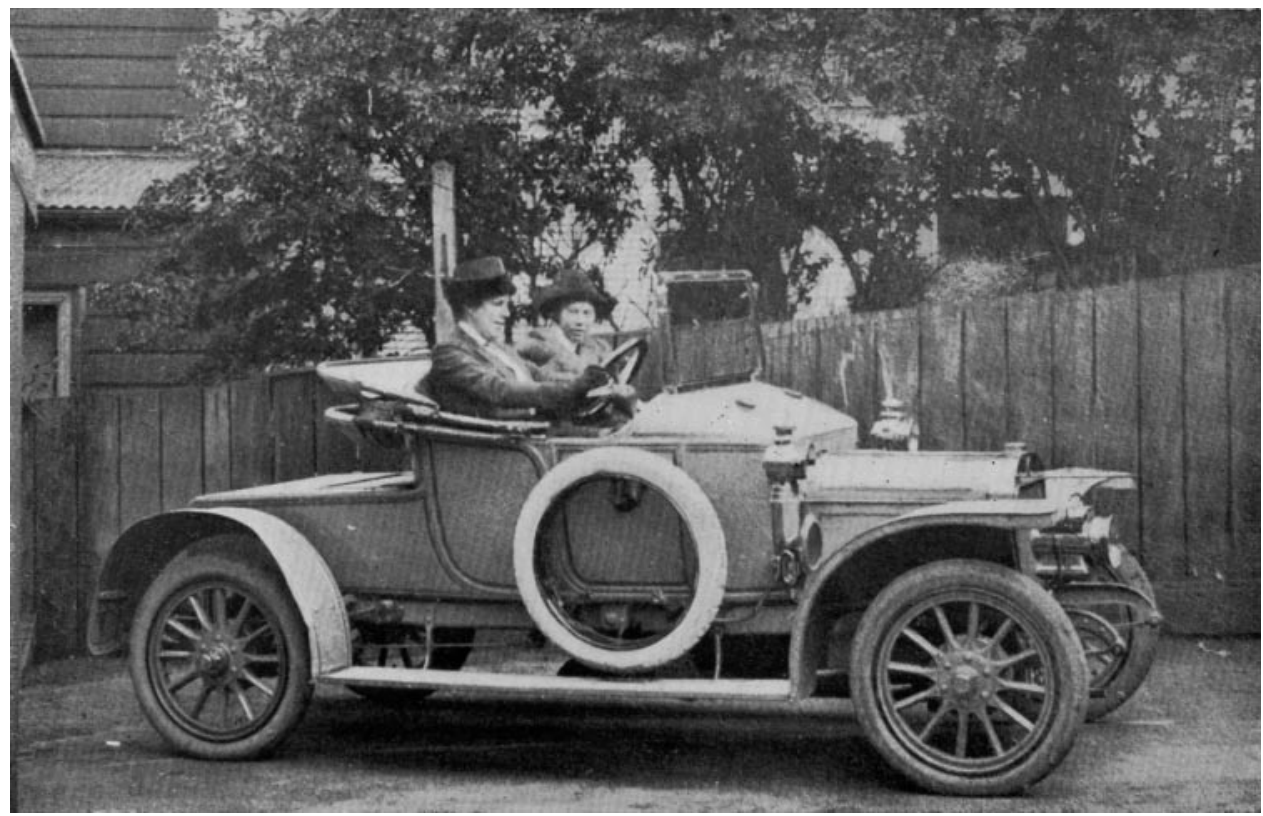

Figure 2: Agnes Bennett and Kate Hogg, Wellington, c. 1914. (Photo from Cecil Manson and Celia Manson, Dr Agnes Bennett, London, Michael Joseph, 1960, opposite p. 128.)

Women's Hospitals in the First World War, for the Australian Flying Doctor Service after retirement, and as a locum in the remote Chatham Islands well into her seventies. What happened to Patrick is uncertain, Kate Hogg married and gave up medicine, but Eleanor Sproull's quest for a community took her through support for the suffrage movement before the First World War-she found the militant Women's Social and Political Union to be "splendid"112 - to conversion to Catholicism. She joined the Sisters of Mercy in 1916, an order with a particular commitment to health care. ${ }^{113}$ By becoming a religious, she finally found "a sense of restfulness, of stability". ${ }^{114}$

\section{Conclusion}

Agnes Bennett's career trajectory took her far from home and she ended up practising outside her native country. This was by no means untypical of the early women graduates. Of the four women who gained Royal University of Ireland degrees in 1891, for example, one remained in Ireland, one went to Australia and two to India. ${ }^{115}$ According to Irene

${ }^{112}$ Bennett, Agnes. Papers. MS-Papers-1346-218. ATL, NLNZ. Letter from Eleanor Sproull, 8 July 1910.

${ }^{113}$ Sister Imelda, 'Contribution of the Sisters of Mercy to nursing', History of Nursing Society Journal, 1994/5, 5: 128-32, p. 129.

\footnotetext{
${ }^{114}$ Bennett, Agnes. Papers. MS-Papers-1346-219.

ATL, NLNZ. Letter from Eleanor Sproull, [1916?]

${ }^{115}$ Finn, op. cit., note 7 above, p. 107, n.33.
} 


\section{Barbara Brookes}

Finn's study, in 1900 one-third (about 150) of all British and Irish medical women "were listed under the category 'abroad' ". Nearly 100 of these were missionary doctors in India and twenty-three worked in China, a number of whom were recipients of grants given by missionary societies to assist with training in the expectation that the women would join the mission field. ${ }^{116}$ Wendy Mitchinson suggests that barriers to women's progress in Canada may have been an important impetus to many becoming medical missionaries. ${ }^{117}$ Medical men also travelled in search of work, and indeed had opportunities unavailable to women in the army, navy and the Indian Medical Service, but they may have found it easier to create a family life in their new localities.

In the first decade of the twentieth-century women were trying to enter a profession already seen to be highly competitive. Anne Digby has noted how the rapid rise in the number of doctors in Britain between 1881 and 1911 (a 62.7 per cent increase) led to fears of an overcrowded profession. ${ }^{118}$ If they could not find work in Britain, women doctors sought careers abroad. Few had the means to aspire to Elizabeth Blackwell's injunction not "to enter upon medicine as a trade for getting money, but from a higher motive". ${ }^{119}$ Agnes Bennett borrowed the money for her training and, she noted, "that wretched debt was to hang like a millstone round my neck for five years after I had qualified". ${ }^{120}$

The mission field provided women with the support of a community of faith and service. Women doctors who tried to make their own way in the provincial towns of England, Australia and New Zealand lacked the advantages of such natural social circles. Unlike male doctors who could enjoy the company of fellow professionals, women were often unwelcome colleagues. Male doctors might expect company at home by marrying and raising families but for women doctors such a choice might entail abandonment of a hard won career. Elston's British study suggests that marriage bars began hardening from the 1890s. ${ }^{121}$ Evidence from America and New Zealand suggests that most women doctors in the late nineteenth and early twentieth centuries led single lives. ${ }^{122}$ As women alone, they might be suspect among married couples of the same social class, and poor incomes (about half that of male doctors ${ }^{123}$ ) made it difficult for them to live in the style expected of professionals.

No longer able to live communally in college, dispersed across the country, indeed across the world in search of work, the unanticipated cost of a career was loneliness, a cost which the inspiring biographies of the pioneers failed to count. ${ }^{124}$ The early pioneers were of the generation which Esther Pohl Lovejoy described as "on the outside standing together" whereas the women of the 1890 s onwards were "inside sitting alone". ${ }^{125}$

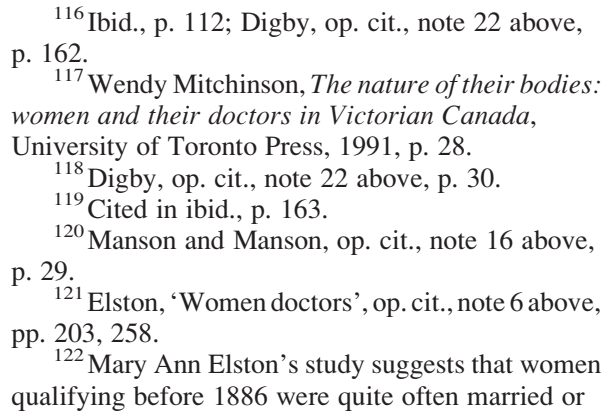

widowed. It was the "second generation" of medical graduates, entering medical training relatively young, who were to face formal marriage bars, and were less likely to marry. Elston, 'Women doctors', op. cit., note 6 above, p. 170

${ }^{123}$ Digby, op. cit., note 22 above, pp. 169-72.

${ }^{124}$ Martha Vicinus, Independent women: work and community for single women, 1850-1920, London, Virago, 1985, explores the world of the women's colleges in ch. 4.

${ }^{125}$ Esther Pohl Lovejoy, Women doctors of the world, New York, Macmillan, 1957, p. 97, cited in Drachman, op. cit., note 8 above, p. 71 . 


\section{Dr Agnes Bennett and her Friends of the 1890s}

In order to counter solitude, letters to their friends from student days seem, as Mary Booth wrote to Agnes Bennett, "to have become a necessary condition of [their] existence". ${ }^{126}$

Correspondence was vital in sustaining this group of "bachelor women", as they described themselves, because however geographically distant, they could be sure that each knew the particular circumstances that being a woman doctor entailed. In these letters we find a discursive creation of social life. Letters provided a place where professional women, expected to be authoritative, could express their vulnerability. For this welleducated and highly literate group, writing provided a way "of expressing and exploring their innermost feelings": the letters voice an introspection otherwise difficult to access. ${ }^{127}$ Handwriting brought the correspondents literally into touch and letters might be read many times. They served to defeat space and make the absent present. ${ }^{128}$ Usually written when their authors were free from interruptions, the letters allowed this group of women to engage in sustained discussion of ideas about the women's movement, marriage and the role of the woman doctor.

The women correspondents discussed here relied on each other for emotional support, looked forward eagerly to opportunities to meet, and felt a great loss when a friend married. The letters under examination are, of course, not a record of complete lives but through them we can see the vicissitudes of life for women starting a medical career in the first decade of the twentieth century. For these individuals at least, they suggest that entry into general practice was difficult for a woman, unless she could afford to work voluntarily and devoted herself to the interests of women and children. ${ }^{129}$ "[T] Sproull enviously of a financially independent friend, "[that] having means makes one's relations to life very different". ${ }^{130}$ Success in the business of medicine was often elusive.

On a return visit to England in 1925, Agnes Bennett found that some things had changed while others had not. Reading a paper to the Obstetrical and Gynaecological Society "was a perfect nightmare":

If it had not been for the niceness of the women I'd have been frozen stiff- these men ... seem to have to surround themselves in a sort of aura of chilliness \& are afraid to be genial \& they intensify it by immaculate clothes, immaculate grooming \& a ridiculous affectation of minute door plates which annoy me intensely for I am living in the midst of them \& can't read their doorplates unless I go right up to them!!

On the other hand, "the women have found themselves extraordinarily since the war-they do anything and wear anything". To Agnes, the women exuded a new freedom signified by their riding breeches, shingled hair, smoking and riding motorcycles. They were, she thought, "much more interesting looking than the men!" 131 A younger generation appeared to be grasping new opportunities.

\footnotetext{
${ }^{126}$ Bennett, Agnes. Papers. MS-Papers-1346-187. ATL, NLNZ. Letter from Mary Booth, 10 Aug. 1893.

${ }^{127}$ Cécile Dauphin, 'The power of writing and women', in Bharati Ray (ed.), Women and politics: France, India and Russia, Calcutta, K P Bagchi, 2000, pp. 56-68, p. 63.

${ }^{128}$ This paragraph is indebted to the discussions at the Correspondence Colloquium, Victoria University of Wellington, 23 and 24 June 2006.
}

\footnotetext{
${ }^{129}$ Digby, op. cit., note 22 above, ch. 7, contains an excellent discussion of women and general practice.

${ }^{130}$ Bennett, Agnes. Papers. MS-Papers-1346-218. ATL, NLNZ. Letter from Eleanor Sproull, 9 Sept. 1909.

${ }^{131}$ Bennett, Agnes. Papers. MS-Papers-1346-218. ATL, NLNZ. Agnes Bennett to Ada Patterson, 1 June 1925 .
} 


\section{Barbara Brookes}

The letters to Agnes Bennett convey some of the hidden and unspoken costs to women who embarked on a medical career in the early 1900s. The shining example of Elizabeth Garrett Anderson, doctor, wife and mother, was difficult to follow. ${ }^{132}$ Remaining unmarried meant that duty to family was paramount, whether or not one had a profession. The avenues of state employment which opened up for women doctors because of their apparently natural sympathy with women and children were often low status, bureaucratic and held little of the scientific interest that had first attracted them to medicine. The new state posts also led to a hardening of marriage bars, making more stark the choice between marriage and a career. ${ }^{133}$ Loneliness was a spur to the formation of new types of communities: women's clubs, the Medical Women's Federation, the Federation of University Women and, in Bennett's case, the foundation of a hostel for women students at Victoria University of Wellington (opened in 1908). ${ }^{134}$ In her involvement in the latter we can see a memorial to the time of great friendships that medical school brought her; friendships that were maintained through correspondence, and which continued to sustain her throughout a long and active career.

\footnotetext{
${ }^{132}$ The influence of Garrett Anderson as a role model is mentioned by Moana Gow who enrolled at Otago in 1916. Dorothy Page, 'Dissecting a community: women medical graduates at the University of Otago, 1891-1924', in Brookes and Page (eds), op. cit., note 9 above, p. 114.
}

\footnotetext{
${ }^{133}$ Elston, 'Women doctors', op. cit., note 6 above, p. 261.

${ }^{134}$ Frances Porter, Home away from home: the story of Victoria House, Wellington, Bridget Williams Books, 2002, pp. 6-7.
} 